\title{
KONTRIBUSI PERBANKAN SYARIAH DALAM PENGEMBANGAN USAHA EKONOMI MIKRO DI BIMA
}

\author{
Jairin ${ }^{1}$ \\ STIS AL-ITTIHAD Bima \\ rienata_31@yahoo.com
}

Kata kunci:
Perbankan
Syariah,
Ekonomi Mikro

\begin{abstract}
Abstrak
Perubahan tataran hidup masyarakat di Bima dengan dipengaruhi oleh berbagai tataran media, membuat pergeseran terhadap tataran dan pola hidup Masyarakat Bima, mulai dari tatacara pengembangan Ekonomi maupun terhadap persaingan trust terhadap kinerja baik kinerja Bank Syariah maupun pada kinerja perbankan konfesional. Pada Era modern segala lini informasi didapati oleh masyarakat Bima, Kemudian diuraikan mengenai isu-isu strategis pendidikan di kancah internasional maupun nasional. Masalah rendahnya kualitas pendidikan kita pun tidak luput dari perhatian artikel ini. pada bagian berikutnya, artikel ini mengangkat pengembangan ekonomi syariah, and influancing develop islam perbankan terhadap peningkatan ekonomi masyarakat di Bima in modern era ini. Asumsi yang mendasari artikel ini ialah era modeen mempunyai implikasi terhadap perlunya reformasi pendidikan dan ekonomi di Bima. Tujuannya agar pendidikan mempunyai kemampuan untuk mengakomodasi, mengantisipasi, dan merespons tantangan dan perubahan yang sedang dan akan terjadi. Sebaliknya, jika tidak dilakukan pembaharuan, maka pendidikan di Indonesia akan ketinggalan oleh irama perubahan
\end{abstract}

Keyword:

Sharia Banking, Micro Economy

\begin{abstract}
Changes in the level of life of the people in Bima are influenced by various levels of media, making a shift to the level and lifestyle of the Bima Community, ranging from economic development procedures to trust competition on the performance of both Sharia Bank performance and confessional banking performance. In the modern era all lines of information were found by the Bima community, and then elaborated on the strategic issues of education in the international and national arena. The problem of the low quality of our education does not escape the attention of this article. In the next section, this article raises the development of Islamic economics, and influancing the development of Islamic banking to improve the economy of the community in the modern Bima in this era. The assumption underlying this article is the modeen era has implications for the need for education and economic reform in Bima. The goal is that education has the ability to accommodate, anticipate, and respond to challenges and changes that are and will occur. Conversely, if no renewal is carried out, then education in Indonesia will be left behind by the rhythm of change.
\end{abstract}




\section{A. Pendahuluan}

Pada saat ini kita sudah memasuki abad ke-

21 atau milenium ketiga yang disebut-sebut sebagai era globalisasi. Ciri utama era modern adalah terjadinya persaingan yang makin ketat, tetapi pada saat bersamaan kerjasama dankesalingtergantungan juga makin kuat. Sebagian orang juga menyebut era sekarang dan yang akan datang sebagai "the age of comlexity and chaos" yang ditandai oleh usangnya berbagai teori lama serta cara berfikir linier dan konvensional dalam menghampiri persoalan yang dihadapi. Sebagai penggantinya, dituntut cara pendekatan baru, teori baru, perspektif baru, karena realitas persoalan yang dihadapi juga berbeda dengan di masa-masa sebelumnya. Sementara sebagian orang lagi, seperti Akbar S. Ahmed (2001:43) menyebutkan bahwa sentral era modern adalah kapitalisme, demokrasi, dan "kesamaan" gender (equality); yang terakhir

${ }^{1}$ Akbar S. Ahmed, Kualiti konsep Pelayanan Publik. (Jakarta Tinta Press, 2001 Hal. 43) ini justru ditolak oleh seluruh utusan dunia Islam dengan disodorkannya konsep "kesetaraan" (equity).

Pertanyaan pokok dan mendasar yang ingin dijawab oleh artikel ini adalah: bagaimanakah meningkatkan kualitas pendidikan di era globalisasi? Tapi sebelum menjawab pertanyaan ini kiranya perlu dipertanyakan pula: seberapa besar keberhasilan atau kegagalan pendidikan nasional kita? Atau secara lebih khusus lagi, seberapa besar keberhasilan atau kegagalan sekolah kita? Kemudian, model ekonomi yang bagaimanakah yang sangat sesuai dengan agama, budaya bangsa, dan tantangan globalisasi? Untuk menjawab pertanyaan pokok dan mendasar yang pertama kiranya perlu dibuat patokanpatokan, atau ukuran-ukuran keberhasilan dan kegagalan suatu pendidikan. Secara umum pendidikan, terutama persekolahan, diadakan dengan tujuan untuk mencapai 4 hal berikut: (1) peningkatan kecerdasan, (2) peningkatan keterampilan hidup, 
peningkatan akhlak dan moralitas, dan (4)

peningkatan keimanan dan ketakwaan, atau keberagamaan $^{2}$. Marilah kita evaluasi satu persatu tolok-ukur keberhasilan atau kegagalan pendidikan itu.

Di era modern yang membuat "bingung" sebagian besar masyarakat ini agama menjadi tempat kembali yang paling menentramkan. Tapi persoalannya untuk bisa hidup secara lebih baik - dalam artian material - diperlukan penguasaan IPTEK yang lebih tinggi. Sekolah umum hanya memberikan kepuasan dalam penguasaan IPTEK saja, sementara sekolah Islam dan madrasah hanya memberikan kepuasan dalam penguasaan AGAMA. Masyarakat menghendaki suatu lembaga pendidikan yang mengunggulkan segi IPTEK dan AGAMA sekaligus. Di bidang ekonomi, tampaknya pendidikan ekonomi syari`ah sebagai alternatif. Di sinilah peluang bagi pengembangan pendidikan Islam di era globalisasi.

2 (1) peningkatan kecerdasan, (2) peningkatan keterampilan hidup, (3) peningkatan akhlak dan moralitas, dan (4) peningkatan keimanan dan ketakwaan, atau beragamaan

\section{B. ERA MODERN DAN MANAJEMEN PENDIDIKAN ISLAM}

\section{Pengertian Modern Era}

Menurut Rizqullah (2005: 47) $)^{3}$, pada dasarnya modern Era merupakan fenomena komersial, bukan politik, yang didorong oleh para pengusaha dan pedagang, bukannya oleh para politisi atau birokrat. Tantangan paling sulit yang berhubungan dengan globalisasi adalah tantangan yang dihadapi para pebisnis. Namun demikian, walaupun akarnya komersial, globalisasi telah menimbulkan masalah-masalah social, politik, dan budaya yang sangat besar. Sebagai misal, inisiatif-inisiatif NAFTA mulai mengaburkan batasan-batasan Negara. Ini bukan berarti batasan Negara dilemahkan, tapi para politisi harus bersungguh-sungguh mengkaji ulang sejumlah asumsinya tentang peranan pemerintahan. Apa pun alasannya,

3 Rizqullah (2005). Masa Depan Perbankan Syari'ah Indonesia. Jakarta. CV. Pena Ilmu 
globalisasi jelas-jelas telah mengubah sudut pandang politisi modern.

Untuk memahami modern era, Syarif, Hidayat $(2004: 65)^{4}$ menjelaskan empat konteks penggunaan istilah globalisasi. Pertama, (toy businessman) menganggap globalization is a set of fact about suppliers, customers, and workers. Jadi, globalisasi adalah seperangkat fakta tentang barang, pelanggan dan pekerja. Woo tidak mempermasalahkan banyak persepsi yang bertentangan mengenai kapitalisme yang mempengaruhi kehidupan. Ia tidak menggunakan istilah globalisasi selain untuk "pemasaran". Dalam kasus ini, ungkap Micklethwait, John \& Wooldridge, Adrian (2000: 56) $)^{5}$, memang tidak seperti orang pada umumnya yang memandang globalisasi sebagai alasan jitu untuk segala-galanya.

4 Syarif, Hidayat. Peningkatan Kualitas SDM Menyongsong Era Globalisasi. (Surabaya. Intan Perkasa 2004. Hal. 47)

${ }^{5}$ Micklethwait, John \& Wooldridge, Adrian . A Future Perfect: The Challenge and Hiddin Promise of Globalization, (New York: Crown Publishers. 2000 Hal. 56)
Kedua, di kalangan pemerintahan, penggunaan istilah globalisasi mengacu pada upaya men-justifikasi sesuatu untuk mempertahankan nilai tukar yang bersifat fix, bukannya untuk perbaikan pendidikan. Ketiga,bagi penganut budaya konservatif, globalisasi merupakan isyarat yang mengacaukan mereka dari dunia modern. Keempat, bagi orang di dunia industri dengan teknologi tinggi, globalisasi merupakan satu dari sejumlah kata yang harus dibuktikan. Dalam beberapa hal yang menyebabkan terjadinya perubahan kehidupan dunia, mitos tentang globalisasi merupakan sesuatu yang tidak dapat dihindarkan.

Menurut Syarif, Hidayat (2004:90), ${ }^{6}$ terdapat lima mitos globalisasi: globalisasi menggiring kemenangan bagi perusahaan besar, (2) globalisasi menggiring pada era produk universal, (3) globalisasi

\footnotetext{
${ }^{6}$ Syarif, Hidayat (2004). Peningkatan Kualitas SDM Menyongsong Era Globalisasi. ( Surabaya. Intan Perkasa. 2004 Hal: 90)
} 
dapat mengakhiri perputaran bisnis tradisional, (4) globalisasi merupakan permainan menang-kalah, dan globalisasi mengandung arti bahwa keberadaan geografis tidak menjadi permasalahan. Kelima mitos di atas tidaklah benar.

Pertama, tidak benar bahwa hanya perusahaan besar saja yang akan menjadi pemenang. Kedua, tidak sepenuhnya benar globalisasi menggiring pada era produk universal. Sebagai contoh Coca-cola, tetap saja harus beradaptasi dengan kekuatan local. Ketiga, bisnis tradisional tidaklah tersisihkan. Namun karena globalisasi ini juga perusahaan tradisional mengikuti perkembangan global yang bukan mustahil akan berperan dalam era globalisasi. Keempat, keyakinan dan kenyataan bahwa globalisasi mencerminkan sebuah. Kelima, maksud dari mitos "globalisasi mengandung arti bahwa keberadaan geografis tidak menjadi permasalahan" adalah tidak adanya batas bagi ruang udara dan langit dalam kaitannya dengan media komunikasi seperti internet, media elektronik, dan teknologi siber.

2. Bagaimana dan Mengapa terjadinya Globalisasi

Globalisasi bukanlah sesuatu yang sama sekali baru bagi umat manusia, termasuk bagi kita bangsa Indonesia. Globalisasi yang diartikan sebagai semakin terbukanya lalu lintas manusia, barang, jasa, dan informasi antarnegara, sesungguhnya telah terjadi sejak dulu kala. Dengan demikian, globalisasi yang terjadi sekarang merupakan kelanjutan dari waktu-waktu sebelumnya, tapi tentunya dengan intensitas dan ekstensitas yang lebih tinggi.

Globalisasi adalah suatu tatanan di mana dunia menjadi begitu terbuka dan transparan sehingga seakan-akan tidak ada lagi batas antar negara. Kecenderungan inilah yang oleh Karim, Adiwarman Azwar $(2005: 65)^{7}$

7 Karim, Adiwarman Azwar. Implementasi Ekonomi Syariah di Indonesia. (Bogor. Tinta Aksara. (2005. Hal: 65) 
disebut sebagai the borberless world. Globalisasi terutama dan dimulai dalam bidang informasi dan ekonomi yang kemudian mempunyai implikasi pada bidang-bidang lain.

Globalisasi merupakan suatu keniscayaan karena didorong dan dipercepat oleh 3 (tiga) faktor berikut:

\section{a. Teknologi.}

Telepon, televisi, komputer dan internet merupakan produk-produk teknologi yang mendorong terjadinya globalisasi. Telepon sebenarnya telah ada sejak satu abad yang lalu. Komputer pun sudah lebih tua kalau dihitung sejak mesin hitung Charles Baggage. Namun kedua peralatan itu mengglobal pada era 1990-an., ditambah lagi dengan kebijakkan langit terbuka (opensky policy ) yang dianut Indonesia. Dalam hal ini, Indonesia memang berada pada posisi yang unik - bisa dilihat sebagai menguntungkan atau tidak menguntungkan karena berada di bentangan garis Khatulistiwa yang paling panjang di dunia yang sangat ideal untuk tempat "mangkal"nya satelit. Teknologi virtual yang berkembang mampu menghubungkan orang yang satu dengan lainnya dari negara yang berlainan. Jarak antar Negara hampir-hampir sudah tidak terbatas. $(1997: 87)^{8}$ menyebut hal ini dengan "kematian jarak". Selanjutnya adanya digitalisasi dan internet membuat globalisasi semakin bermakna. Saat ini hampir semua sudut kehidupan dimasuki oleh kedua produk teknologi modern tersebut, bahkan semakin menjadi virtual. Web (jaringan) atau situs-situs bertebaran di alam maya.

\section{b. Pasar Modal.}

Faktor pendorong kedua dari globalisasi adalah pasar modal. Jumlah modal yang bergulir saat ini jauh lebih banyak dari sebelumnya. Kecepatan pergerakannya lebih cepat, dan rasio modal pada barang-barang

8 Supriadi, Dedi. Globalisasi dan Pendidikan: Implikasi pada Perguruan Swasta Menghadapi Abad Ke-21. (Makassar. Duta Perkasa. 1997: Hal; 87) 
yang diperdagangkan lebih besar. Tapi konsekuensi-konsekuensi dari suatu kesalahan juga makin dahsyat. Namun dari pengalaman yang ditunjukkan Korea Selatan menunjukkan betapa semakin besarnya pengaruh pasar modal di dunia. Pasar tidak hanya mengikat ekonomi dan mengubah struktur perusahaan- perusahaan, tapi juga mengubah sistem politik secara keseluruhan.

c. Metode Manajemen.

Faktor pendorong yang ketiga dari globalisasi adalah metode manajemen. Dulu sebuah perusahaan hanya berada di satu wilayah negara. Sekarang, dengan kemudahan investasi di hampir setiap negara, memungkinkan pengalihan perusahaan dari suatu wilayah negara ke wilayah negara lain. Sebuah perusahaan dapat membuka cabang di negara lain dengan kantor pusatnya tetap berada di negara asalnya. Selain itu cara merger pun dilakukan. Suatu perusahaan pada suatu negara mengadakan merger dengan perusahaan sejenis di negara lain.
3.Globalisasi, Filsafat Materialisme, dan Islam

Benarkah globalisasi sebagai pen-SATU-an dunia di bawah komandan Amerika Serikat? Bila demikian, apa landasan filosofis globalisasi yang dibangun oleh Negara adidaya itu? Ada berbagai komentar orang tentang globalisasi. Kata Micklethwat \& Wooldridge, para pemimpin Perancis dan Asia mensinonimkan globalisasi dengan "dominasi" Amerika Serikat.

Menurut Ahmed Rifa'i (2002: 32) ${ }^{9}$, sentral Globalisasi adalah kapitalisme, demokrasi, dan "kesamaan" gender (equality); yang terakhir ini justru ditolak oleh seluruh utusan dunia Islam dengan disodorkannya konsep "kesetaraan" (equity).

\section{Knowledge Based Economy}

Dalam Islam, ilmu pengetahuan memiliki kedudukan yang utama. Banyak ayat yang memuji orang yang memiliki ilmu

\footnotetext{
${ }^{9}$ Ahmed Rifa'i . Pendidikan dan Perubahan Sosial Ekonomi. (Yogyakarta: Aditya Media. 2002 Hal. 32)
} 
pengetahuan, antara lain disebutkan dalam

Surat Al-Mujadilah ayat 11, "niscaya Allah meninggikan derajat orang-orang yang beriman di antaramu dan diberi ilmu pengetahuan beberapa derajat".

Era Global dikenal sebagai era informasi, yang menurut. Coombs, Philip H. (1999: 54) ${ }^{10}$ merupakan gelombang ketiga dari peradaban manusia (pertanian, industri, dan informasi). Masyarakat yang dituntut di era ini adalah juga masyarakat informasi atau masyarakat belajar. Mari kita lihat struktur perekonomian nasional kita. Ada empat sector perekonomian kita, yaitu: (1) pertanian, (2) industri, (3) perdagangan dan jasa, dan (4) minyak dan gas bumi. Ketika ekonomi kita tertumpu pada sektor pertanian, pendidikan tidak begitu menjadi tuntutan. Dengan pendidikan ala kadarnya, bahkan tanpa pendidikan sekalipun anak-

10 Coombs, Philip H. The World Crisis in Education: The View from the Eightie. ( New York: Oxford University Press. 1999. Hal. 21) anak petani dapat menjadi petani yang sukses (saat itu).

Apa implikasinya bagi pembangunan pendidikan nasional kita? Pembangunan pendidikan oleh sebagian pakar disebut sebagai gejala penawaran (supply phenomena) dan oleh lainnya disebut sebagai gejala permintaan (demond phenomena). Jika dipandang sebagai gejala penawaran (supply phenomena), maka persoalan pokoknya terpusat pada bagaimana menghasilkan lulusan sebanyakbanyaknya dan bagaimana pula meningkatkan mutu pendidikan itu sendiri. Tapi jika dipandang sebagai suatu gejala permintaan (demond phenomena), maka persoalan utamanya adalah: untuk apa lulusan dihasilkan dan untuk apa pula mutu pendidikan ditingkatkan. Menurut Karim, Adiwarman Azwar (2005: 45) ${ }^{11}$ pembangunan pendidikan perlu dipandang sebagai gejala permintaan (demond

${ }^{11}$ Karim, Adiwarman Azwar. Implementasi Ekonomi Syari'ah di Indonesia. (Bogor. Tinta Aksara. 2005 Hal 45) 
phenomena) yang berorientasi pada segi "manfaat".

Karena investasi pendidikan memerlukan waktu yang panjang, maka dibutuhkan suatu idiologi. Menurut Boediono, amanat Pembukaan UUD 1945 yang utuh perlu diangkat sebagai idiologi pendidikan kita, yaitu: "... memajukan kesejahteraan umum, mencerdaskan kehidupan bangsa, dan ikut melaksanakan ketertiban dunia ...". ${ }^{12}$ Dengan demikian, pembangunan pendidikan bukan hanya diorientasikan padapeningkatan mutu pendidikan, melainkan juga peningkatan taraf hidup sejalan dengan kemajuan ilmu pengetahuan.

Sektor perekonomian kita sekarang dan terlebih-lebih di masa depan membutuhkan

- meminjam istilah Micklethwait, John \& Wooldridge, Adrian (2000:43) ${ }^{13}$ knowledge

${ }^{12}$ Baca amanat Pembukaan UUD 1945 yang utuh perlu diangkat sebagai idiologi pendidikan kita, yaitu: "... memajukan kesejahteraan umum, mencerdaskan kehidupan bangsa, dan ikut melaksanakan ketertiban dunia ...".

13 Micklethwait, John \& Wooldridge, Adrian (2000). A Future Perfect: employee, bukan sekedar employee dan terlebih-lebih lagi worker. Perbedaan employee dengan worker sebagai berikut: (1) Worker menggunakan ketrampilan yang relatif menetap, sedangkan employee terus menerus meningkatkan pengetahuannya, (2) mesin menentukan pekerjaan apa yang harus dilakukan oleh worker, sedangkan employee dapat memutuskan apa yang harus dilakukan oleh mesin, (3) worker harus diawasi melalui span of control sepanjang garis organisasi, sedangkan employee alih-alih span of control, untuk employee hanya ada span of responsibility, dan (4) employee memiliki means of production, yakni "informasi", sedangkan worker tidak memilikinya.

5.Reorientasi Manajemen Pendidikan:

Empat Pilar Pendidikan Memasuki era globalisasi, pendidikan harus menyebarkan secara masal pengetahuan dan ketrampilan The Challenge and Hiddin Promise of Globalization, (New York: Crown Publishers. 2000. Hal 43) 
kerja yang terus berkembang, diadaptasikan dengan peradaban dan didorong oleh pengetahuan. Pendidikan harus secara simultan menyediakan peta dunia yang rumit dan kalut, serta sebagai kompas bagi para pelajar untuk menemukan jalan keluarnya sendiri.

Agar tugas-tugas tersebut berhasil, maka pendidikan harus didasarkan pada empat pilar pendidikan yang paling fundamental, yang sepanjang hayatnya dapat dikatakan sebagai sokoguru pengetahuan, sesuai dengan pandangan Amir Hamzah (2009: 86) ${ }^{14}$ yaitu:

a. Belajar untuk mengetahui (learning to know)

Belajar bukan hanya untuk memperoleh informasi yang sudah dirinci dan disusun secara sistemik, melainkan untuk menguasai instrumen-instrumenpengetahuan, baik sebagai alat ataupun sebagai tujuan hidup. Sebagai alat, instrumen-instrumen 14 Amir hamzah. Posmodernisme: Bahaya dan Harapan Bagi Islam, terjemahan. (Bandung. Intan Preest. 2009 Hal. 86) pengetahuan diharapkan dapat memberikan wawasan kepada setiap peserta didik untuk: (a) memahami lingkungannya agar dapat hidup berharkat di tengah-tengah masyarakatnya, mengembangkanketrampilan kerja, dan (c) untuk dapat berkomunikasi. Sedangkan sebagai tujuan, instrumen-instrumen pengetahuan diharapkan mendorong peserta didik agar gemar untuk mengetahui, memahami, dan menemukan. Metode ilmiah perlu dibekalkan kepada peserta didik. Ringkasnya, peserta didik perlu dibekalkan pendidikan umum yang memadai dan spesialisasi yang mendalam.

Di era globalisasi ini bahasa asing, khususnya Bahasa Inggris, memegang peranan penting sebagai kunci pembuka berbagai ilmu pengetahuan. Referensi ilmu pengetahuan dewasa ini kebanyakan berbahasa Inggris. Bahasa asing lainnya pundiperlukan jika peserta didik itu memiliki ketrampilan kerja yang diperlukan suatu bangsa. Dewasa ini negara-negara 
Arab misalnya saja memerlukan sekitar sepuluh ribu perawat dari Indonesia. Di samping menguasai bidang-bidang keperawatan, para pelajar dan mahasiswa keperawatan kita perlu memiliki bekal Bahasa Arab.

b. Belajar berbuat (learning to do)

Belajar untuk berbuat lebih terkait erat dengan bidang vokasional. Tapi bidang vokasional yang bagaimanakah yang dapat membekalkan peserta didik agar dapat beradaptasi dengan kemajuan teknologi yang sangat cepat.

Pertama, dari ketrampilan ke kompetensi. Kemajuan teknologi yang sangat cepat tak terhindarkan menuntut suatu kompetensi yang lebih bersifat mental dan intelektual, ketimbang ketrampilan psikomotorik belaka. Kedua, dematerialisasi pekerjaan dan berkembangnya sektor jasa. Ketiga, pergeseran bekerja dari sektor formal ke ekonomi informal. Belajar hidup bersama (learning to life together). b. Belajar menjadi seseorang (learning to be)

Tujuan utama pendidikan adalah membangun manusia seutuhnya agar mampu berpikir kritis dan mandiri dalam membuat suatu keputusan untuk kehidupannya. Pendidikan harus membekalkan kemampuan kepada peserta didik untuk memecahkan masalahmasalahnya sendiri, mengambil keputusan sendiri, dan memikul tanggung-jawab sendiri. Dengan berbekalkan ketiga pilar pendidikan (belajar mengetahui, belajar untuk bekerja, dan belajar hidup bersama) maka peserta didik perlu memiliki kemampuan memadukannya sehingga ia menjadi seseorang yang berharga.

Kesatu, dengan terjadinya revolusi buku dan informasi perlu dibekalkan pengetahuan yang paling esensial. Selain itu perlu dilatihkan ketrampilan learning how to learn . Pendekatan pengajaran jangan ditekankan pada penguasaan materi, melainkan kemampuan belajar. Model pendidikan CTL 
(Contekstual Teaching and Learning), portofolio, dan STS (Sciences, Technology and Society) perlu diakrabi oleh setiap pendidik dan peserta didik. Metode inkuiri, discovery, dan metode ilmiah perlu mendominasi pengajaran kita.

Kedua, agama dan sejarah merupakan bidang-bidang yang memotivasi seseorang untuk hidup berharga di tengah-tengah masyarakatnya dan masyarakat dunia. Dalam Islam, Al-Quran adalah "Bacaan Harian", artinya harus dibaca setiap hari. Persoalannya, bagaimanakah Al-Quran yang cukup tebal itu dikuasai dan menjadi pedoman hidup siswa. Diperlukan suatu pendekatan khusus bagaimanakah agar para siswa memiliki motivasi yang tinggi untuk selalu mengkaji Al-Quran. ${ }^{15}$

\section{PERLUNYA EKONOMI SYARI'AH}

\section{Konsep Harta dalam Islam}

Allah Swt telah menganugerahkan rizki yang luas dan harta yang banyak bagi umat

${ }^{15}$ Baca Al-Quran sebagai salah satu Sciences, Technology and Society manusia. Jika dikelola dengan benar dan adil, maka tidak akan ada seorang manusia pun di muka bumi ini yang akan menghadapi kelaparan. Tapi pada kenyataannya, sepanjang sejarah selalu banyak saja manusia yang sulit mencari sesuap nasi sekalipun. Banyak umat manusia yang mati kelaparan.

Mengapa bisa terjadi demikian? Karena adanya segelintir manusia yang sangat kuat dan amat serakah. Memang, tanpa bimbingan dari Allah manusia tidak bias mengelola bumi dengan benar dan adil. Oleh karena itulah Allah Swt menurunkan Nabinabi sebagai khalifah-khalifahnya di muka bumi. Allah Swt berfirman dalamAlQuranul Karim, "bumi diwariskan kepada hamba-hamba-Ku yang saleh.” Hanya manusia-manusia salehlah yang layak memimpin bumi.

Oleh karena itulah dalam Islam harta harus diperoleh secara halal. Orang yangdianugerahi kekayaan harus membayar zakat, infaq, shodaqoh, dan menyembelih 
hewan qurban. Wakaf sangat dianjurkan bagi orang-orang kaya. Tangan yang di atas (simbol orang yang senang memberi) dimuliakan. Ada hadits Nabi Saw yang menyebutkan al-yadul `ulya khoerum min yaadis-sufla" (tangan yang di atas lebih baik daripada tangan yang di bawah). Demikian juga bekerja keras mencari harta yang halal sangat dipuji oleh Islam.

Kemiskinan merupakan musuh Islam yang harus dihilangkan. Bahaya miskin adalah bisa menjurus menjadi kufur. Sabda Nabi Saw $^{16}$ "Kadzal faqro ayyakuna kufron" (Kefaqiran itu bisa menjurus pada kekufuran). Supaya orang-orang faqir tidak menjadi kufur, maka mereka harus disejahterakan. Cerita pemurtadan lewat indomie dan supermie mungkin sudah terdengar oleh kita semua. Na udhu billahi min dzalik.

Mengapa Islam mengharamkan riba, pencurian, dan penipuan, karena semua

${ }^{16}$ Nabi Muhammad SAW Bersabda, Kadzal faqro ayyakuna kufron" (Kefaqiran itu bisa menjurus pada kekufuran) perbuatan ini merusak harta. Karena itu segala upaya pengrusakan terhadap harta seperti korupsi, pemerasan, dan segala transaksi bisnis yang menguntungkan satu pihak dan merugikan pihak lainnya diharamkan. Sebaliknya, segala upaya peningkatan kesejahteraan dan pengentasan kemiskinan sangat dianjurkan oleh Islam.

2. Konsep Dasar Ekonomi Islam

Konsep dasar Islam adalah tauhid atau meng-Esa-kan Allah. Tauhid di bidang ekonomi adalah menempatkan Allah sebagai Sang Maha Pemilik yang selalu hadir dalam tiap nafas kehidupan manusia muslim. Dengan menempatkan Allah sebagai satusatunya Pemilik maka otomatis manusia akan ditempatkan sebagai pemilik "hak guna pakai" yang bersifat sementara terhadap harta yang dimilikinya.

Dengan demikian realitas kepemilikan mutlak oleh manusia tidak dibenarkan dalam Islam, sebab hal ini berarti mengingkari tauhid; atau istilah lainnya melakukan syirik-Pengaturan, dan orangnya disebut 
musyrik atau musyrik-Pengaturan. Padahal syirik itu merupakan dosa yang paling besar.

Dalam Al-Quran Disebutkan" Inna syirka ladzulmun ‘adzim" (sesungguhnya syirik itu merupaka dosa yang paling besar).

Islam memang mengakui hak setiap individu sebagai pemilik atas apa yang diperolehnya melalui bekerja dalam pengertian yang seluas-luasnya, dan manusia berhak untuk mempertukarkan haknya itu dalam batasbatas yang telah ditentukan dalam hukum Islam. Persyaratan-persyaratan dan batasbatas hak milik dalam Islam sesuai dengan kodrat manusia itu sendiri, yaitu dengan sistem keadilan dan sesuai dengan hak-hak semua pihak yang terlibat di dalamnya.

Contohnya, si-A bercocok tanam dengan sistem pengairan tadah hujan. Ia membeli bibit tanaman seharga Rp. 200.000. Ia pun kemudian membajak tanah dan menanam bibit tanaman itu. Setelah 2,5 bulan ia memetik hasil panenan. Karena curah hujan bagus dan udara mendukung, ia memperoleh panenan yang baik senilai Rp. 2.000.000.
Berapa rupiahkah sebenarnya hasil usaha siA? Orang serakah akan mengatakan Rp. 1.800.000 (Rp. 2.000.000 - Rp. 200.000). Tapi manusia beriman akan memperhitungkan faktor anugrah alam, yakni curah hujan yang bagus dan udara yang mendukung. Sekiranya curah hujan dan udara tidak mendukung apa hasilnya akan sama? Pasti berbeda. Mungkin hasil panenannya hanya Rp. 1.000.000. Dengan memperbandingkan faktor alam dalam contoh kasus ini, nalar manusia yang sehat akan mengatakan betapa besarnya anugrah Allah dalam setiap rizki dan harta yang kita peroleh. Di sinilah letak logisnya bahwa dari setiap hasil usaha dan harta itu ada hak Allah yang diperuntukkan bagi manusia yang berhak menerimanya.

Contoh lainnya, petani kapas. Dari modal kerja sendiri senilai Rp. 10 juta ia menghasilkan panenan sebanyak 1 ton. Harga per-kg-nya Rp. 20.000 yang berarti menjadi Rp. 20 juta. Dengan demikian laba kotornya hanya Rp. 10 juta. Ia ingin 
melebihkan hasil panenan dengan cara mengolah sebagian kapas menjadi benang, katakanlah ia mampu mengerjakannya sendiri 100 kg (berarti kapasnya tinggal 900 kg lagi). Misalkan, harga benang per-kg Rp. 50.000 yang berarti Rp. 5 juta. Jadi hasil panenan dia sebesar Rp. 18 juta $(900$ kg kapas x Rp. 20.000) + Rp. 5 juta $(100$ kg benang x Rp. 50.000) = Rp. 23 juta.

Petani kapas itu ingin lebih melipatkan lagi hasil panenannya, yaitu dengan cara mengubah seluruh kapasnya menjadi benang, tentunya dengan mengambil tenaga kerja. Dengan demikian hasil panenannya menjadi 1 ton benang x Rp. $50.000=$ Rp. 50 juta. Artinya, dengan bekerja sendiri petani kapas itu menghasilkan Rp. 23 juta. Tapi dengan mengangkat tenaga kerja hasilnya berlipat menjadi Rp. 50 juta. Pertanyaannya, berapa rupiahkah hak para pekerja? Di sinilah terjadi perbedaan tajam antara sistem ekonomi Islam dengan sistem ekonomi lainnya. Dalam system ekonomi kapitalistik faktor kerja tidak diperhitungkan. Para buruh dianggap budak yang bisa dibayar seenaknya saja. Upah buruh ditentukan oleh bos/majikan. Karena kesulitan mendapatkan rizki, maka para buruh mau saja dibayar berapa saja, dibayar murah sekali pun.

Sebaliknya, Islam justru memperhitungkan faktor kerja dan nilai tambah yang berkeadilan . Dalam kasus petani kapas tadi, hasil kerja murni dia sebenarnya hanya Rp. 23.000.000. Dengan demikian, nilai tambah yang Rp. 27.000.000 adalah hasi kerja bersama antara petani kapas dengan para pekerjanya. Berapa rupiahkah dari $\mathrm{Rp}$. 27.000.000 itu yang menjadi hak petani dan berapa rupiah pula yang menjadi hak para pekerja, sistem ekonomi Islam mengaturnya secara berkeadilan dan menghindari eksploitasi. Jadi, hak milik perorangan didasarkan atas kebebasan individu yang wajar dan kodrati, sedang kerjasama didasarkan atas kebutuhan dan kepentingan bersama.

Menurut ajaran Islam, manfaat dan kebutuhan akan materi adalah untuk 
kesejahteraan seluruh umat manusia, bukan hanya untuk sekelompok manusia saja. (Ismail Raji al-Faruqi, 2002: 205) ${ }^{17}$. Dalam ajaran Islam terdapat dua prinsip utama ekonomi, yakni:

pertama, tidak seorangpun atau sekelompok orang pun yang berhak mengeksploitasi orang lain; dan kedua , tidak ada sekelompok orang pun boleh memisahkan diri dari orang lain dengan tujuan untuk membatasi kegitan ekonomi di kalangan mereka saja. Dengan demikian seorang muslim harus memiliki pemikiran bahwa kegiatan perekonomian pada akhirnya akan kembali berada di tangan Allah. Islam memandang umat manusia sebagai satu keluarga, maka setiap manusia adalah sama derajatnya di sisi Allah dan di depan hukum Islam.

Untuk merealisasi kekeluargaan dan kebersamaan tersebut, harus ada kerjasama

17 Ismail Raji al-Faruqi. Menumbuhkan Kekuatan Ekonomi Ummat Melalui Pembangunan Lembaga Keuangan Syari'ah. Bandung. Dunia Ilmu 2002: 205 dan tolong menolong. Konsep persaudaraan dan perlakuan yang sama terhadap seluruh anggota masyarakat di muka hukum tidaklah ada artinya kalau tidak disertai dengan keadilan ekonomi yang memungkinkan setiap orang memperoleh hak atas sumbangannya terhadap masyarakat. Agar tidak ada eksploitasi yang dilakukan seseorang terhadap orang lain, maka Allah melarang umat Islam memakan hak orang lain. Dalam Qs. Asy-Syu`ara ayat 183 Allah SWT berfirman: "Dan janganlah kamu merugikan manusia pada hak-haknya dan janganlah kamu merajalela di muka bumi dengan membuat kerusakan"18 Dengan komitmen Islam yang khas dan mendalam terhadap persaudaraan dan keadilan ekonomi, maka segala bentuk kezaliman dalam perolehan harta bertentangan dengan Islam. Tentu saja makna adil di sini bukan

${ }^{18}$ Dalam Qs. Asy-Syu ara ayat 183 Allah SWT berfirman: "Dan janganlah kamu merugikan manusia pada hak-haknya dan janganlah kamu merajalela di muka bumi dengan membuat kerusakan 
semua orang harus mendapat upah yang sama tanpa memandang kontribusinya kepada masyarakat. Islam mentoleransi ketidaksamaan pendapatan sampai tingkat tertentu, karena setiap orang berbeda sifat, kemampuan, dan pelayanannya dalam masyarakat. Dalam Al-Quran disebutkan: "Dan Allah melebihkan sebagian kamu dari sebagian yang lain dalam hal rizki..." (Qs. 16/al-Nahl: 71). ${ }^{19}$

\section{Nilai-nilai Sistem Ekonomi Islam}

Menurut Didin Hafidhuddin (2005: 32) ${ }^{20}$,

Sistem ekonomi Islam perlu dibangun atas dasar tiga nilai-nilai berikut:

a. Nilai Tauhid

1. Keyakinan kepada Allah SWT sebagai pemberi rizki (Qs. 11/Hud: 6), pemberi dan pembuat aturan untuk kemaslahatan hidup umma tmanusia (Qs. 30/Ar-Rum: 30,

${ }^{19}$ Dalam Qs. 16/al-Nahl: 71. Yang artinya Dan Allah melebihkan sebagian kamu dari sebagian yang lain dalam hal rizki

${ }^{20}$ Didin Hafidhuddin. Dasar Hukum Ekonomi Islam. (Bandung. CV. Intan Perkasa 2005. Hal. 32) sekaligus yang mewajibkan manusia untuk mencari rizki dan karuniaNya (Qs. 67: 15) untuk kemudian dipertanggung-jawabkan kelak kemudian hari di hadapan-Nya.

b. Keadilan dan kesejahteraan bersama, menurut Prof. Abd. Mannan (2005:52) yakni:

1. Tidak boleh harta dikuasai kelompok tertentu saja (Qs. 59: 7).

2. Menghapuskan monopoli, kecuali oleh pemerintah, untuk bidangbidang tertentu.

3. Menjamin hak dan kesempatan semua pihak untuk aktif dalam proses ekonomi, baik produksi, distribusi, sirkulasi maupun konsumsi.

4. Menjamin basic needs fulfillment (pemenuhan kebutuhan-kebutuhuan dasar hidup) setiap anggota masyarakat.

5. Melaksanakan amanah at-Takaaful al-Ijtima'I atau social economic 
security insurance di mana yang mampu menanggung dan membantu yang tidak mampu.

6. Jangan mengatakan sistem ekonomi syari'ah bila outputnya tidak bermanfaat bagi masyarakat/ummat.

7. Pengenaan kewajiban $\rightarrow$ zakat (Qs. 9/At-Taubat: 60; Qs. 30/ArRum: 39).

c. Kebebasan dan tanggungjawab

Dalam ekonomi Islam dikenal prinsip Tsawabit / تباوث (tetap dan pasti) dan Mutaghayyirat / تاريغَتْت untuk melaksanakan prinsip yang bias dikembangkan sesuai dengan kebutuhan yang memerlukan inovasi dan kreatifitas. Beberapa contoh prinsip:

1) Tidak boleh menipu dan berlaku curang (Qs. 83: 1-6 \& al-Hadits).

2) Tidak boleh saling mendzalimi (Qs. 2/Al-Baqarah: 279).

3) Tidak boleh melakukan kegiatan usaha yang haram dan bathil (Qs.
2/Al-Baqarah:188; Qs. 5/al-Maidah: 90-91).

4) Tidak boleh melakukan kegiatan riba, sebagaimana tercantum dalam Qs. 2/Al-Baqarah: 275-279).

Catatan: Membungakan uang adalah sama dengan riba, karena itu bunga hukumnya haram. Haramnya bunga telah ditetapkan pula oleh:

1. Majelis Tarjih Muhammadiyyah (Sidoarjo, 1968)

2. Lajnah Bahtsul Masaail Nahdatul Ulama (Bandar Lampung,1982).

3. Sidang Organisasi Konfrensi Islam (OKI) di Islamababad,1970.

4. Sidang MUFTI Negara Mesir, Kairo 1989.

5. Konsul Kajian Islam Dunia, 1965.

6. Kajian Islam dan Fatwa Kerajaan Saudi Arabia.

7. Komisi Fatwa Majelis Ulama Indonesia, 2003.

8. Lembaga Keuangan Syari`ah 
Sebelum membicarakan lembaga keuangan syari ah, terlebih dahulu perlu dikemukakan berbagai upaya penguatan ekonomi ummat, terutama melalui: (1) Lembaga Keuangan Syari'ah, yakni "Dana dari ummat untuk ummat"; (2) Pembiayaan untuk sektor riel yang dikelola ummat; dan (3) Melakukan sinergi (ta'awun) dengan lembaga keuangan mikro yang dimiliki ummat, seperti BPRS, BMT, dan Lembaga Zakat (BAZ dan LAZ). Meskipun BAZ dan LAZ secara umum ditujukan untuk kepentingan mustahik zakat. Hal yang juga penting untuk dilakukan dalam memberdayakan dan membangun kekuatan ekonomi ummat adalah dengan mengoptimalkan pengambilan dan pendistribusian zakat, infak dan shadaqah melalui lembaga yang amanah, transparan dan professional. Lembaga zakat ini (baik LAZ maupun BAZ) harus di isi oleh orangorang yang memiliki kafaah syar'iyyah dan kemampuan manajerial dan memiliki waktu yang cukup. Lembaga zakat ini harus memiliki program kerja yang jelas, data muzakki dan mustahik dan kesediaan untuk diaudit oleh auditor netral. Demikian pula wakaf, baik wakaf harta benda yang tidak bergerak seperti tanah dan bangunan maupun wakaf dengan uang harus dioptimalkan pelaksanaannya.

Secara empirik sudah dibuktikan bahwa wakaf memiliki peran dan fungsi yang kuat untuk membangun kekuatan ekonomi, seperti contoh di Bangladesh. Demikian pula untuk kepentingan dan kemajuan pendidikan seperti di Universitas Al-Azhar Kairo dan Lembaga-lembaga Pendidikan terkemuka di Indonesia.

Adapun perbedaan antara Lembaga Keuangan Syari'ah (seperti Bank, dan Asuransi Syari'ah) dengan Lembaga Keuangan Konvensional. Akad dan aspek legalitas. Akad yang dilakukan memiliki konsekuensi duniawi dan ukhrawi, karena 
akad yang dilakukan berdasarkan hukum Islam. $^{21}$

\section{a. Struktur Organisasi.}

Lembaga Keuangan Syari'ah dapat memiliki strukturyang sama dengan Lembaga Keuangan Konvensional, misalnya dalam hal komisaris dan direksi, dan bagian-bagian lainnya, tetapi unsur yang amat membedakan Lembaga Keuangan Syari’ah dengan Lembaga Keuangan Konvensional adalah keharusan adanya Dewan Pengawas Syari'ah yang bertugas mengawasi operasional bank dan produk-produknya agar sesuai dengan garis-garis syari'ah.

b. Bisnis dan Usaha yang Dibiayai.

Dalam Lembaga Keuangan Syari'ah, bisnis dan usaha yang dilaksanakan tidak terlepas dari saringan syari'ah. Karena itu, Lembaga Keuangan Syari'ah tidak akan mungkin membiayai usaha yang terkandung di dalam nya hal-hal yang diharamkan, madharat dan bertentangan dengan nilai-nilai Islam.

\footnotetext{
${ }^{21}$ Antoni safi,i. Sistem manejemen kineja Bank syariah dan Bank konfensional (Jakarta. Insan Permata Press. 2004) Hal. 79
}

c. Lingkungan Kerja dan Corporate Culture Sebuah Lembaga Keuangan Syari'ah selayaknya memiliki lingkunagn kerja yang sejalan dengan syari'ah. Dalam hal etika, misalnya sifat shiddiq dan amanah, harus melandasi setiap karyawan sehingga tercermin integritas eksekutif muslim yang baik. Disamping itu, karyawan Lembaga Keuangan Syari'ah harus skillful dan professional (fathanah) dan mampu melaksanakan tugas secara team work dimana informasi merata diseluruh fungsional organisasi (tabligh). Demikian pula dalam hal reward dan punishment, diperlukan prinsip keadilan yang sesuai dengan syari'ah.

\section{Konsep Bank Islam (Bank Syari`ah)}

Dalam beberapa hal, bank konvensional dan bank syari'ah memiliki persamaan, terutama dalam sisi teknis penerimaan uang, mekanisme transfer, teknologi komputer yang digunakan, syarat-syarat umum memperoleh pembiayaan seperti KTP. NPWP, proposal, laporan keuangan dan 
sebagainya. Namun, terdapat banyak perbedaan mendasar di antara keduanya. Menurut Didin Hafidhuddin $(2005: 92)^{22}$ perbedaan itu menyangkut aspek legal, struktur organisasi, usaha yang dibiayai dan lingkungan kerja.

a. Akad Dan Aspek Legalitas.

Dalam bank syari'ah, akad yang dilakukan memiliki konsekuensi duniawi dan ukhrawi, karena akad yang dilakukanberdasarkan hukum Islam. Seringkali nasabah berani melanggar kesepakatan/perjanjian yang telah dilakukan bila hukum itu hanya berdasarkan hukum positif belaka, tapi tidak demikian bila perjanjian tersebut memiliki pertanggungjawaban hingga yaumil qiyamah nanti. Setiap akad dalam perbankan syari'ah, baik dalam hal barang, pelaku transaksi, maupun ketentuan lainnya harus memenuhi ketentuan akad.

${ }^{22}$ Didin Hafidhuddin. Dasar Hukum Ekonomi Islam. (Bandung. CV. Intan Perkasa 2005. Hal. 92) b. Lembaga Penyelesai Sengketa.

Berbeda dengan per-bank-an konvensional, pada perbank-an syari'ah jika terdapat perbedaan atau perselisihan antara bank dengan nasabahnya, maka kedua belah pihak tidak menyelesaikannya dengan peradilan negeri, tetapi menyelesaikannya sesuai dengan tata cara dan hokum syari'ah. Lembaga yang mengatur hukum materi dan atau berdasarkan prinsip syari'ah di Indonesia dikenal dengan nama Badan Arbitrase Mu'amalah Indonesia atau BAMUI yang didirikan secara bersama oleh Kejaksaan Agung Republik Indonesia dan Majelis Ulama Indonesia.

c. Struktur Organisasi.

Bank Syari'ah dapat memiliki struktur yang sama dengan Bank Konvensional, misalnya dalam hal komisaris dan direksi. Tapi unsur yang amat membedakan antara bank syari'ah dengan bank konvensional adalah keharusan adanya Dewan Pengawas 
Syari'ah yang bertugas mengawasi operasional bank dan produk-produknya agar sesuai dengan garis-garis syari'ah.

\section{d. Bisnis Dan Usaha Yang Dibiayai.}

Dalam Bank Syari'ah, bisnis dan usaha yang dilaksanakan tidak terlepas dari saringan syari'ah. Karena itu bank syari'ah tidak akan mungkin membiayai usaha yang terkandung di dalamnya halhal yang diharamkan.

Dalam perbank-an syari'ah suatu pembiayaan tidak akan disetujui sebelum dipastikan beberapa hal pokok. Didin Hafidhuddin $\quad(2005: \quad 65)^{23}$
mengungkapkannya dalam pertanyaan-pertanyaan berikut:

a. Apakah objek pembiayaan halal atau haram?

b. Apakah proyek menimbulkan kemudharatan bagi masyarakat?

c. Apakah proyek berkaitan dengan perbuatan mesum/asusila?

\footnotetext{
${ }^{23}$ Didin Hafidhuddin. Aliran Dana Bank
} Syariah (Intan Press. Jakarta. 2005. Hal: 65) d. Apakah proyek berkaitan dengan perjudian?

e. Apakah usaha itu berkaitan dengan industri senjata ilegal atau berorientasi pada pengembangan senjata pembunuh massal?

f. Apakah proyek dapat merugikan syi'ar Islam, baik secara langsung atau tidak langsung?

g. Lingkungan Kerja Dan Corporate Culture.

Sebuah bank syari'ah selayaknya memiliki lingkungan kerja yang sejalan dengan syari'ah. Dalam hal etika, misalnya sifat amanah dan shiddiq harus melandasi setiap karyawan sehingga tercermin integritas eksekutif muslim yang baik. Di samping itu karyawan bank syari'ah harus skillful dan professional (fathonah) dan mampu melaksanakan tugas secara team-work di mana informasi merata di seluruh fungsional organisasi (tabligh). Demikian pula dalam hal reward dan punishment, diperlukan prinsip keadilan yang sesuai dengan 
syari'ah. Selain itu cara berpakaian dan tingkah laku dari para karyawan merupakan cerminan bahwa mereka bekerja dalam sebuah lembaga keuangan yang membawa nama besar Islam, sehingga tidak ada aurat yang terbuka dan tingkah laku yang kasar.

Demikian pula dalam menghadapi nasabah, akhlaq harus senantiasa terjaga. Nabi Muhammad Saw. mengatakan bahwa senyum adalah shadaqah. Adapun perbedaan antara Bank syari'ah dengan Bank Konvensional dapat diperhatikan dalam tabel pada halaman berikut:

TABEL 1

PERBEDAAN BANK SYARI'AH DENGAN BANK KONVENSIONAL*)

\begin{tabular}{|l|l|l|}
\hline NO & $\begin{array}{l}\text { BANK } \\
\text { SYARI'AH/ISLAM }\end{array}$ & $\begin{array}{l}\text { BANK } \\
\text { KONVENSIONAL }\end{array}$ \\
\hline 1 & $\begin{array}{l}\text { Melakukan investasi- } \\
\text { investasi yang halal } \\
\text { Saja dan dikontrol } \\
\text { oleh DPS }\end{array}$ & $\begin{array}{l} \\
\text { Berdasarkan prinsip } \\
\text { bagi hasil, jual beli, } \\
\text { atau sewa }\end{array}$ \\
\hline 3 & $\begin{array}{l}\text { Profit dan falah } \\
\text { beunga }\end{array}$ \\
\hline 2 & Profit Oriented \\
\hline
\end{tabular}

\begin{tabular}{|l|l|l|}
\hline & $\begin{array}{l}\text { dan } \\
\text { kebahagiaan akhirat) } \\
\text { oriented }\end{array}$ & \\
\hline 4 & $\begin{array}{l}\text { Hubungan dengan } \\
\text { nasabah } \\
\text { bentuk } \\
\text { hubungan kemitraan }\end{array}$ & $\begin{array}{l}\text { Hubungan dengan } \\
\text { nasabah dalam bentuk } \\
\text { hubungan debitur- } \\
\text { debitur }\end{array}$ \\
\hline 5 & $\begin{array}{l}\text { Penghimpunan dan } \\
\text { penyaluran dana } \\
\text { harus } \\
\text { sesuai dengan Fatwa } \\
\text { Dewan Pengawas } \\
\text { Syari'ah terdapat dewan }\end{array}$ \\
\hline
\end{tabular}

*) Didin Hafidhuddin (2005: 47) $)^{24}$

Akan tetapi untuk mengetahui perbedaan kinerja antara bank Konfesional dengan bank Syariah, yang biasa masyarakat pahami yakni Bank konfesional di kenal dengan suku Bunga dan sedangkan Bank Syariah dikenal dengan Mudarabbah atau lebih dikenal dengan bagi hasil, dan adapun perbedaan antara Bunga Bank dengan system Bagi Hasil sebagai berikut:

TABEL 2

24 Didin Hafidhuddin. Dasar Hukum Ekonomi Islam. (Bandung. CV. Intan Perkasa 2005. Hal. 32) 


\section{PERBEDAAN BUNGA BANK DENGAN}

"BAGI-HASIL" *)

\begin{tabular}{|c|c|c|}
\hline No & BUNGA & HASIL \\
\hline 1 & $\begin{array}{l}\text { Penentuan bunga } \\
\text { dibuat pada waktu } \\
\text { akad dengan asumsi } \\
\text { harus selalu untung }\end{array}$ & $\begin{array}{l}\text { Penentuan besarnya } \\
\text { rasio/nisbah bagi hasil } \\
\text { dibuat pada wakt } \\
\text { akad dengan } \\
\text { berpedoman pada } \\
\text { kemungkinan untung } \\
\text { rugi }\end{array}$ \\
\hline 2 & \begin{tabular}{ll}
\multicolumn{2}{c}{ Besarnya presentase } \\
berdasarkan pada \\
jumlah \\
(modal) yang \\
Dipinjamkan
\end{tabular} & $\begin{array}{lr}\text { Besarnya } & \text { rasio bagi } \\
\text { hasil berdasarkan } \\
\text { pada } & \text { jumlah } \\
\text { keuntungan } & \text { yang } \\
\text { diperoleh. } & \end{array}$ \\
\hline 3 & $\begin{array}{l}\text { Pembayaran bunga } \\
\text { tetap seperti } \\
\text { yang dijanjikan } \\
\text { tanpa pertimbangan } \\
\text { apakah proyek yang } \\
\text { dijalankan oleh } \\
\text { pihak nasabah } \\
\text { untung atau rugi }\end{array}$ & $\begin{array}{l}\text { Bagi hasil tergantung } \\
\text { pada } \\
\text { proyek } \\
\text { dijalankan. Bila usaha } \\
\text { merugi, } \\
\text { akan kerugian } \\
\text { bersama oleh kedua } \\
\text { belah pihak }\end{array}$ \\
\hline 4 & $\begin{array}{l}\text { Jumlah pembayaran } \\
\text { bunga tidak } \\
\text { meningkat sekalipun } \\
\text { jumlah keuntungan } \\
\text { berlipat atau } \\
\text { keadaan ekonomi } \\
\text { sedang "booming" }\end{array}$ & $\begin{array}{l}\text { Bagi hasil tergantung } \\
\text { pada keuntungan } \\
\text { proyek } \quad \text { yang } \\
\text { dijalankan. Bila usaha } \\
\text { merugi, kerugian } \\
\text { akan ditanggung } \\
\text { bersama oleh kedua } \\
\text { belah pihak. }\end{array}$ \\
\hline 5 & $\begin{array}{l}\text { Eksistensi } \\
\text { diragukanga } \\
\text { tidak dikecam) oleh } \\
\text { semua }\end{array}$ & $\begin{array}{l}\text { Tidak ada yang } \\
\text { meragukan keabsahan } \\
\text { bagi hasil }\end{array}$ \\
\hline
\end{tabular}

termasuk Islam

\section{Penutup}

\section{KESIMPULAN}

Dari serangkaian pembahasan tentang krisis agama dan moral, manajemen pendidikan Islam, dan perlunya ekonomi syari`ah di era global, hasilnya bahasannya dapat disimpulkan sebagai berikut:

Era Modern memiliki akar sejarah yang panjang. Tapi proses globalisasi yang cepat terjadi akhir-akhir ini, karena didorong oleh kemajuan teknologi khususnya teknologi komunikasi dan transportasi, pasar modal, dan metode manajemen. Pada akhirnya, globalisasi memiliki implikasi yang besar terhadap pendidikan. Lembaga pendidikan Islam (Madrasah dan Sekolah Islam) dan pendidikan agama dalam sekolah umum perlu berbenah diri untuk menghadapi tantangan globalisasi.

Era Modern yang berbasis filsafat materialisme telah terbukti menciptakan pecahnya jati-diri manusia. Manusia hanya 
mengejar keunggulan dan kesenangan "materi", tapi melupakan jati-dirinya sebagai makhluk yang berdimensi "ruhani" Sebagai sebuah proses yang alamiah dan perlu, maka proses globalisasi mutlak harus diikuti dengan memacu keunggulan IPTEK. Tapi sebagai makhluk yang bersubstansi "ruhani", maka keber-AGAMA-an harus menjadi pengendali penguasaan IPTEK. Pertanyaannya, apa yang harus kita lakukan ? Kita memang harus ta jub dan belajar dari kemajuan sain dan teknologi Negara maju semacam Amerika Serikat. Kita harus mengakui bahwa sain dan teknologi mereka sangat tinggi. Semangat ilmiah mereka harus kita tiru. Semangat belajar dan penelitian mereka harus kita tiru. Semangat bekerja dan mencari nafkah mereka pun harus kita tiru.

Tapi kita jangan silau dengan kemajuan sain dan teknologi mereka. Mereka telah menyalah-gunakan sain dan teknologi untuk memperbudak manusia di seluruh dunia. Mereka menggunakan sain dan teknologi untuk menghancurkan bangsabangsa di dunia. Mereka menggunakan sain dan teknologi untuk mengeruk harta kekayaan bangsa-bangsa muslim dan negara-negara dunia ketiga. Mereka menggunakan sain dan teknologi untuk menghancurkan kebangkitan Islam. Mereka tidak layak menjadi khalifah fil-ardhi. Kita harus melakukan upaya bertahap untuk memajukan Islam. Tahap pertama dan utama adalah melakukan "jihad pembangunan”, “jihad pendidikan", dan "jihad ekonomi syari`ah”.

Human Development Index (HDI) atau Indeks Pembangunan Manusia (IPM) telah dijadikan standar untuk mengukur tingkat kemajuan pembangunan manusia suatu bangsa. Maju-mundurnya pembangunan diukur dari 3 komponen utama, yakni: kesejahteraan, pendidikan, dan kesehatan. Suatu bangsa dikategorikan sebagai bangsa yang maju pembangunan manusianya jika penduduk pada bangsa itu sejahtera-sejahtera, cerdas-cerdas, dan sehat- 
sehat. Sebaliknya, jika bangsa itu miskinmiskin, bodoh-bodoh, dan sakit-sakitan, maka bangsa itu dikaterika mundur pembangunan manusianya.

Bagaimanakah IPM negeri kita, Indonesia? Hasil survey UNDP, IPM Indonesia semakin turun. Dari 174 negara, tahun 1996 Indonesia menempati posisi ke 102, kemudian pada tahun 1999 turun ke posisi 105, tahun 2000 turun lagi ke posisi 109, dan tahun 2003 turun lagi ke posisi 112. Posisi IPM Indonesia selalu berada di bawah rata-rata dunia. Kita harus mendukung pembangunan IPM, karena dengan meningkatkan IPM berarti kita memelihara agama Islam. Tapi, tentu saja, tidak cukup sekedar IPM. Kita harus membangun IPM Plus, yang tidak lain menjaga syari`ah Islam (agama, jiwa, akal, harta, dan kehormatan). Pembangunan paling fundamental yang harus kita lakukan saat ini adalah "pembangunan pendidikan".

Negeri kita perlu melahirkan banyak Ulama. Idealnya di setiap desa ada seorang Ulama yang mumpuni. Lembaga pendidikan calon Ulama (apa Pesantren Tinggi atau IAIN) perlu disupport agar melahirkan banyak Ulama. Para mahasiswa perlu menguasai sain dan teknologi yang disinari Islam. Karena minimnya pendidikan agama di universitas, maka pengayaan Basic Islam dan dan Ilmu-ilmu Islam perlu diberikan kepada mahasiswa

\section{Daftar Pustaka}

Ahmed Rifa'i (2002). Pendidikan dan Perubahan Sosial Ekonomi. Yogyakarta: Aditya Media.

Amir hamzah. (2009). Posmodernisme: Bahaya dan Harapan Bagi Islam, terjemahan. Bandung. Intan Preest.

Coombs, Philip H. (1985). The World Crisis in Education: The View from The Eightie. New York: Oxford University Press.

Didin (2005). Menumbuhkan Kekuatan Ekonomi Ummat Melalui Pembangunan Lembaga Keuangan Syari'ah. Bandung. Dunia Ilmu

Direktorat Sekolah Swasta (Tanpa Tahun), Sekolah Menengah Umum Plus: Informasi Singkat, Jakarta: Direktorat Sekolah Swasta 
Ditjen Pendidikan Dasar dan Menengah

Departemen

Pendidikan dan Kebudayaan.

Hafidhuddin, Didin (2005). Menumbuhkan

Kekuatan Ekonomi Ummat

Melalui Pembangunan Lembaga

Keuangan Syari'ah. Jakarta.

CV. Kreatif Tinta

Karim, Adiwarman Azwar (2005).

Implementasi Ekonomi Syari'ah

di Indonesia. Bogor. Tinta

Aksara.

Maududi, Abul A`la (2003). Khilafah dan

Kerajaan: Evaluasi Kritis atas

Sejarah Pemerintahan Islam.

Bandung. Cetakan Kedua,

Bandung. Dunia Ilmu.

Micklethwait, John \& Wooldridge, Adrian (2000). A Future Perfect: The Challenge and Hiddin Promise of Globalization, New York:

Crown Publishers.

Mizan, Muhammad (2001). Kepemilikan dalam Islam, Jakarta: Pustaka Hidayah

Rahmat, Munawar (2002). Aplikasi Nilainilai Religius dan Peningkatan Mutu Sekolah. Malang. Intan Perkasa.

Rizqullah (2005). Masa Depan Perbankan Syari'ah Indonesia. Jakarta. CV. Pena Ilmu.

Supriadi, Dedi (1997). Globalisasi dan Pendidikan: Implikasi pada Perguruan Swasta Menghadapi Abad Ke-21. Makassar. Duta Perkasa

Syarif, Hidayat (2004). Peningkatan Kualitas SDM Menyongsong Era Globalisasi. Surabaya. Intan Perkasa 